\title{
USGS International Activities in Coal Resources
}

During the last 30 years the U.S. Geological Survey (USGS) has been engaged in coal exploration and characterization in more that 30 foreign countries, including India, Pakistan, China, Turkey, several Eastern European countries, Russia, and other former Soviet Union countries. Through this work, the USGS has developed an internationally recognized capability for assessing coal resources and defining their geochemical and physical characteristics. More recently, these data have been incorporated into digital databases and Geographic Information System (GIS) digital map products. The USGS has developed a high level of expertise in assessing the technological, economic, environmental, and human health impacts of coal occurrences and utilization based on comprehensive characterization of representative coal samples.

Working closely with counterparts in the host countries, the USGS has conducted coal-related studies aimed at solving a variety of problems in numerous international settings, generally with the sponsorship of international donor agencies, such as the U.S. Agency for International Development (USAID) or the Asian
Development Bank. The emphasis of these studies in recent years has been the assessment of coal and coalbed methane resources primarily in nations that are underdeveloped or in transition to market economies. Recent USGS research conducted in cooperation with the USGS World Energy Project has focused on the local and worldwide impacts of the occurrence, development, and use of coal on human health.

Nations which do not possess sufficient energy resources are commonly the most environmentally stressed because of chronic poverty and the lack of infrastructure to provide for clean water and air, efficient waste collection and disposal, adequate transportation and housing, and domestic and commercial electricity. For nations that do not have an abundance of petroleum resources, the orderly development of coal or coal-bed methane resources, or the upgrading of existing coal production and consumption facilities, can lead to viable sources of new energy that are relatively benign environmentally, and that can contribute to long-term political and economic stability.

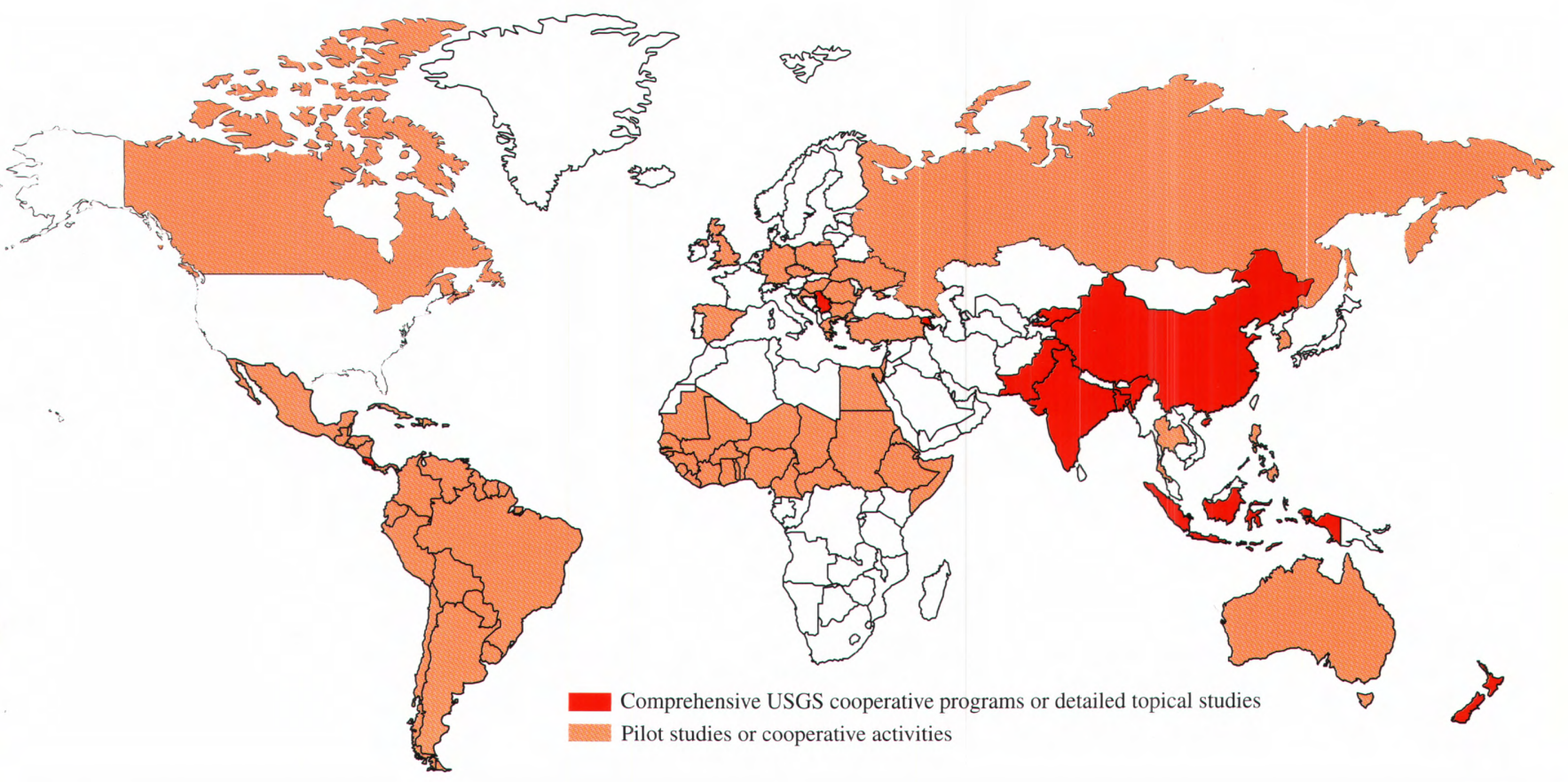

During the last 30 years the U.S. Geological Survey has been engaged in coal exploration and characterization in more than 30 foreign countries and has analyzed coal resources in most regions of the world. 


\section{International Coal Activities of the USGS}

- Environmental impacts of mining, utilization, and mine waste disposal

- Coal characterization

- Human health impacts

- Coal and coal-gas exploration and resource assessment

- Reclamation

- Training and institution building

\section{India}

The USGS is:

- Working with the Geological Survey of India to define the characteristics of industrial coal in the Sohagpur Basin, Madhya Predesh

- Working with the Central Arid Zone Research Institute in Rajasthan on surface mine reclamation

- Working cooperatively with the Central Fuel Research Institute on coal characterization

\section{Pakistan}

The USGS:

- Worked with the Geological Survey of Pakistan (GSP) to define the extent of known coalfields

- Worked with GSP to discover the world-class Thar coalfield

- Established coal petrographic and analytical laboratories in the GSP and Pakistan Center for Scientific and Industrial Research (PCSIR)

- Helped develop scientific institutions in the GSP

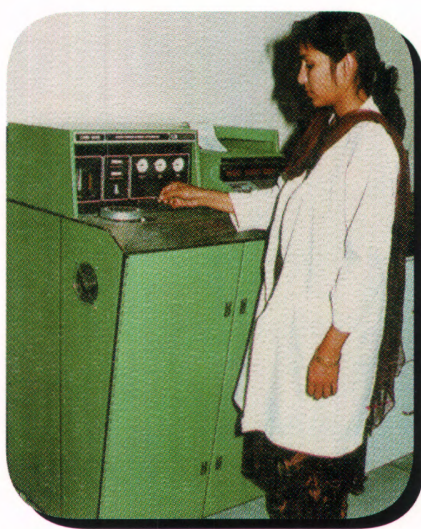

USGS provided GSP and PCSIR with training for use of analytical equipment in Pakistan.

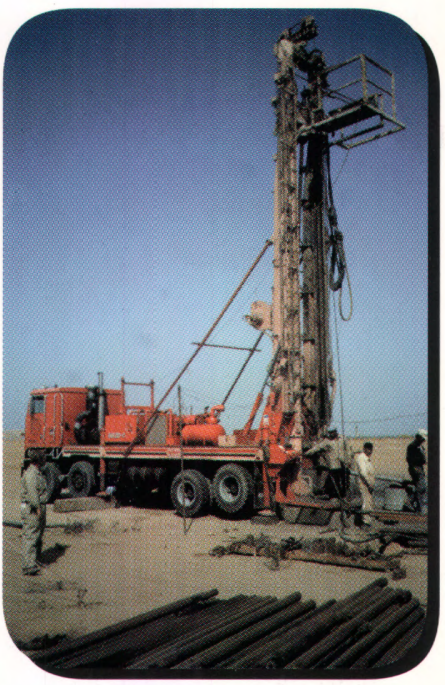

USAID and USGS provided GSP with drilling equipment and training for coal exploration in Pakistan.

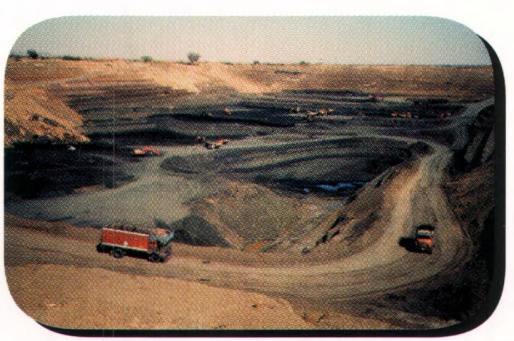

USGS works with Indian agencies on reclamation studies in open-pit mines such as the one shown above.

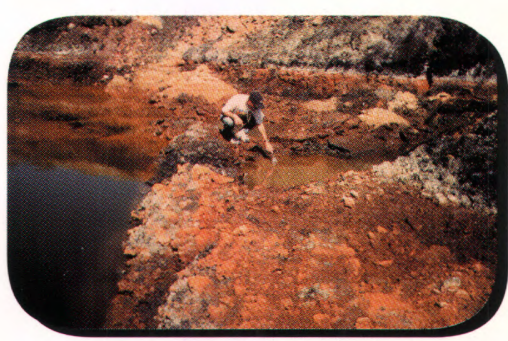

In India, a USGS geologist samples water in an open-pit mine for reclamation studies.

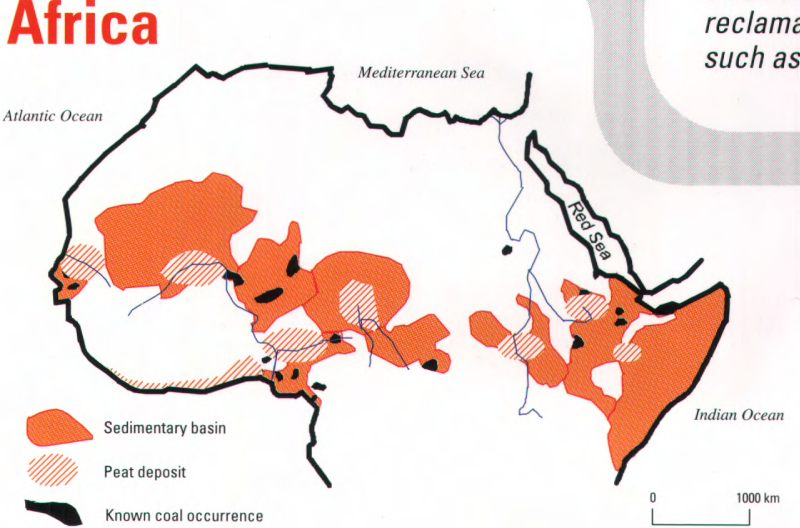

The USGS has:

- Evaluated the coal resource potential of Sub-Saharan and other areas of North Africa

USGS has compiled peat and coal information for Sub-Saharan Africa where the use of indigenous energy resources not currently utilized might help relieve the stress of deforestation associated with using timber for fuel. 


\section{Russia and Newly Independent States}

The USGS has:

- Worked on coal-bed methane assessment in Ukraine and Russia

- Conducted coal exploration and resource assessment in Armenia

- Established a coal characterization laboratory in Armenia

- Worked on coal resource assessment in Kyrgyzstan

\section{Latin America}

The USGS has:

- Developed a digital coal map of South America

- Worked in Costa Rica to explore and characterize that nation's coal deposits

\section{China and Asia}

The USGS conducted:

- Joint Chinese and American investigations of the geology and geochemistry of coal to find causes of various health problems in China

- Coal resource assessments in Bangladesh and the Philippines

- Peat and coal resource studies in Indonesia

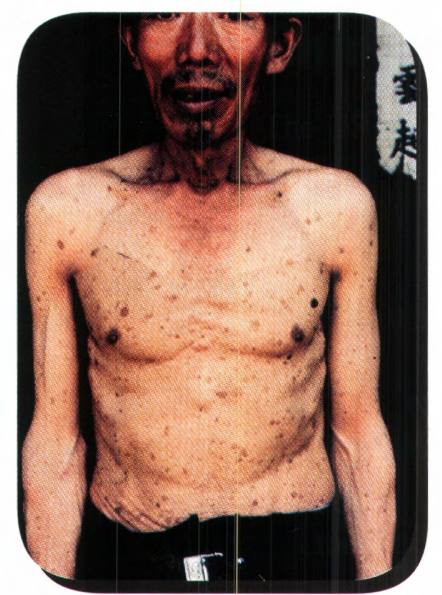

The USGS is working in China to help understand the causes of arsenic poisoning in rural populations. High concentrations of arsenic in coal that is used as cooking fuel often contributes to skin diseases such as keratosis.

\section{Eastern Europe}

The USGS worked on:

- Identification of the probable cause of a widespread kidney disease in southeastern Europe (Balkan endemic nephropathy) as in situ leaching of toxic and carcinogenic organic compounds from lignite beds

- Identification of point sources for several potentially toxic coal-ash pollutants in Yugoslavia and in other areas of Eastern Europe, along with possible mitigating technologies for the recovery of coal-ash byproducts

- Coal resource and coal-bed methane studies in Poland

- Coal resource studies in the Czech Republic

- Coal resource studies in Hungary

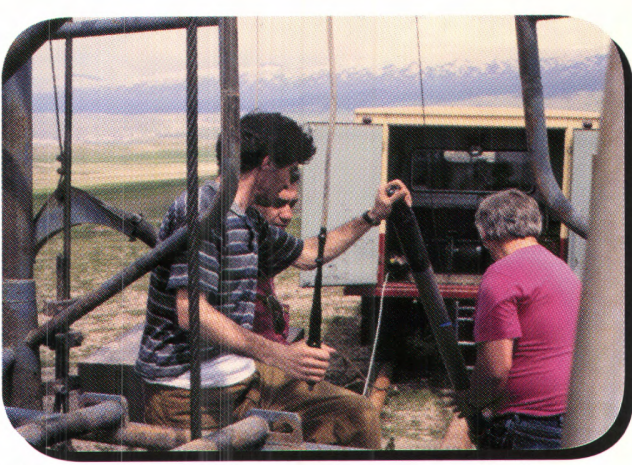

USGS geophysicists work with Armenian counterparts at a drill site in Armenia.

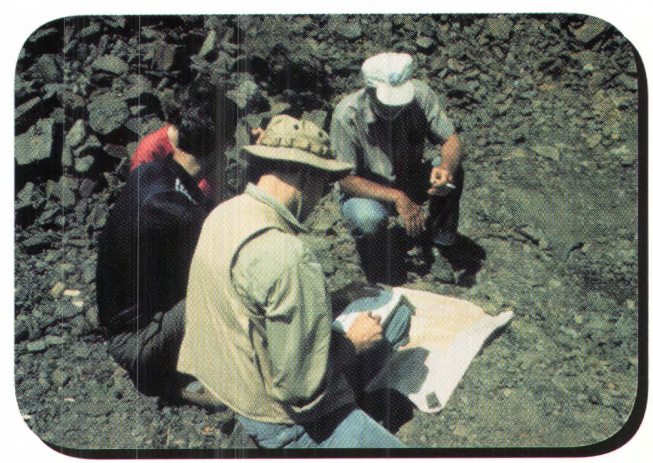

USGS and Armenian geologists work to locate coal deposits in Armenia.

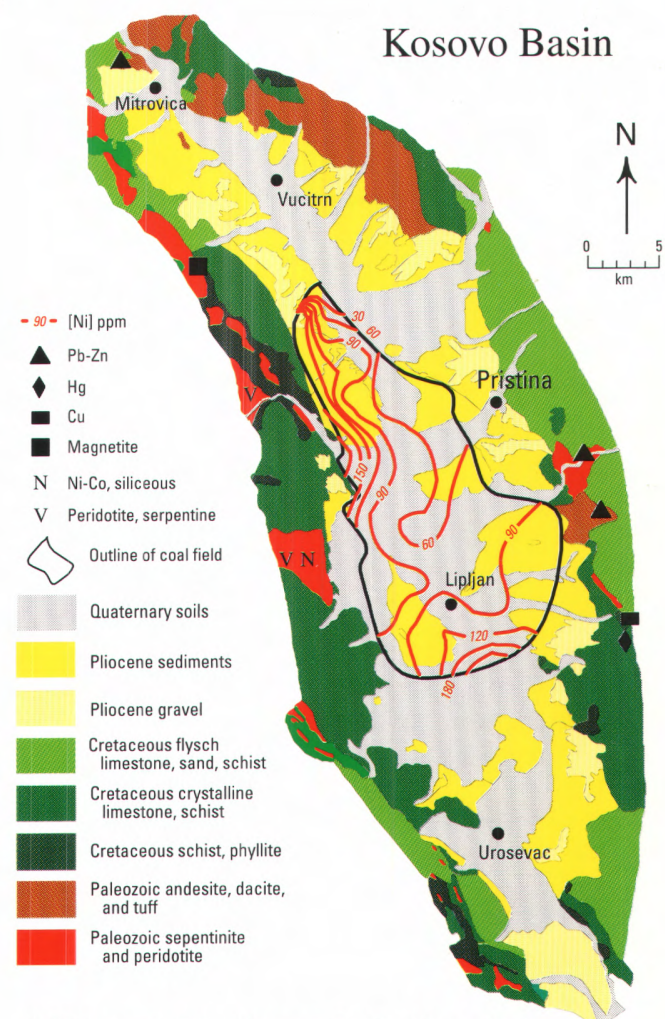

USGS map of the Kosovo Basin, Yugoslavia. Lignite in this area is the source of trace metals that may be economically recoverable. 


\section{General References}

Landis, E.R., and Weaver, J.N., 1993, Global coal occurrence, in Law, B.E., and Rice, D.D., eds., Hydrocarbons from coal: American Association of Petroleum Geologists Studies in Geology 38, p. 1-12.

SanFilipo, J.R., and Warwick, P.D., 1998, Bibliography of selected reports on USGS international coal-related activities: U.S. Geological Survey Open-File Report 98-350, 29 p.

SanFilipo, J.R., and Warwick, P.D., 1995, Selected worldwide coal activities of the U.S. Geological Survey, with emphasis on their environmental applications, in Shiao-Hung Chian (ed.), Coal-Energy and the Environment: Proceedings of the Twelfth Annual International Pittsburgh Coal Conference, 1 tbl., 1 fig., p. $526-531$.

SanFilipo, J.R., and Warwick, P.D., 1995, International coal-related activities of the U.S. Geological Survey and their environmental applications, in Carter, L.M.H. (ed.), Energy and the Environment-Application of Geosciences to DecisionMaking-1995 Program and Abstracts, V.E. McKelvey Forum on Mineral and Energy Resources: U.S. Geological Survey Circular 1108, p. 75-77, 1 fig., 1 tbl.

Warwick, P.D., Landis, E.R., Roberts, S.B., and Johnson, E.A., 1993, Worldwide coal-related activities of the U.S. Geological Survey, in Shiao-Hung Chian (ed.), Coal-Energy and the Environment: Proceedings of the Tenth Annual International Pittsburgh Coal Conference, p. 1052-1055.

Contacts for more information on worldwide coal activities:

\section{Peter Warwick}

U.S. Geological Survey

MS 956 National Center

Reston, VA 20192

Email: pwarwick@usgs.gov

Phone: (703) 648-6469

Fax: (703) 648-6419

\section{John SanFilipo}

U.S. Geological Survey

MS 956 National Center

Reston, VA 20192

Email: jsan@usgs.gov

Phone: (703) 648-6436

Fax: (703) 648-6419

\section{Robert Finkelman}

U.S. Geological Survey

MS 956 National Center

Reston, VA 20192

Email: rbf@usgs.gov

Phone: (703) 648-6412

Fax: (703) 648-6419

\section{Research Facilities at the USGS}

The U.S. Geological Survey maintains state-of-the-art computer and analytical facilities for chemical, mineralogical, and petrographic characterization of coal. USGS staff includes internationally recognized experts on coal geology, and on organic and inorganic characterization of coal. Program scientists routinely conduct resource assessments using integrated Geographic Information Systems (GIS). These scientists are responsible for developing and maintaining the largest publicly available coalquality database in the U.S. and they have recently embarked on a project to develop an international coal-quality database. The widely used domestic database has been adopted by the U.S. Environmental Protection Agency and the Electric Power Research Institute to address environmental and human health issues. These data are available at:

http://energy.er.usgs.gov/products/databases/index.htm or in CD-ROM format.

The U.S. Geological Survey also conducts training in coal geology and environmental science. Courses have been offered in Armenia, the Czech Republic, Israel, Mexico, and Poland, and are given in the U.S. for foreign scientists. Recent cooperating scientists have been from Armenia, Bangladesh, China, Costa Rica, Hungary, India, Indonesia, Israel, New Zealand, Pakistan, and Poland.

Coal and environmental analysis is only as effective and valid as the underlying data. Problems arising from utilization of all fossil fuels transcend international political boundaries, and coal consumed in any nation may impact the environment in the rest of the world. The USGS international coal technical team can provide the rigorous analytical and technical support necessary to address concerns and protocols.

Contacts for information on:

India

\section{Robert Milici}

U.S. Geological Survey MS 956 National Center Reston, VA 20192

Email: rmilici@usgs.gov

Phone: (703) 648-6541

Fax: (703) 648-6419

Africa, Eastern Europe
Michael Brownfield
U.S. Geological Survey
P.O. Box 25046, 939 DFC
Denver, CO 80225
Email: mbrownfield@usgs.gov
Phone: (303) 236-7767
Fax: (303) 236-0459

Africa, Eastern Europe

Michael Brownfield

U.S. Geological Survey

Denver, CO 80225

Phone: (303) 236-7767

Fax: (303) 236-0459

Visit our Web site at: http://energy.er.usgs.gov

\section{Central Asia}

Hal Gluskoter

U.S. Geological Survey MS 956 National Center Reston, VA 20192

Email: halg@usgs.gov

Phone: (703) 648-6429

Fax: (703) 648-6419

\section{Newly Independent States}

Brenda Pierce

U.S. Geological Survey

MS 956 National Center

Reston, VA 20192

Email: bpierce@usgs.gov

Phone: (703) 648-6421

Fax: (703) 648-6419

\section{South Asia \\ John SanFilipo \\ East Asia, Central and South America \\ Peter Warwick}

Coal Quality,

Health Issues,

China, Training

Courses

Robert Finkelman

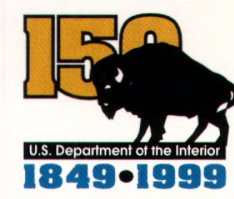

